\title{
Hjelp, jeg har time hos legen!
}

\author{
Den økende ankomsten av inn- \\ vandrere og asylsøkere kan by på \\ nye utfordringer for legestanden. \\ Foruten den generelle belast- \\ ningen av å være tvunget til å leve \\ i eksil, har enkelte psykososiale \\ belastninger og andre tilleggs- \\ vansker. Spørsmålet er om legene \\ er godt nok forberedt til å møte \\ denne utfordringen?
}

Jeg mener at det aller viktigste verktøyet enhver lege trenger i møte med sine pasienter, er å kunne kommunisere med vedkommende. Kommunikasjon er overføring av signaler, verbalt eller ikke-verbalt, fra én person til en annen i den hensikt å frembringe forståelse, en bestemt mening eller en respons hos den andre.

Språkproblemer og andre kommunikasjonsbarrierer kan gjøre det ekstra vanskelig å innta rollen som pasient. Og norsk er ikke et enkelt språk å lære. Pasienter med svært begrensede norskkunnskaper vil derfor kunne trenge lengre konsultasjonstid hos legen. Selv etter lang botid er det ikke alltid like lett å være nyansert i kommunikasjonen med andre. Nyansene i det norske språket kan by på utfordringer. Jeg husker fortsatt mine første år i Norge da det svært ofte hendte at jeg ble usikker på hva legen min egentlig mente. Av respekt unnlot jeg å spørre. Også fordi jeg ikke ville være til bry. I Ghana er legene er en høyt respektert gruppe, og det hadde jeg med meg de første årene i Norge.
Tolk må og skal brukes i mange tilfeller, men som kjent er det ikke alltid like lett å skaffe tolk i det språket man trenger tolk til. Og selv om man klarer å skaffe riktig tolk, behøver ikke tolkingen være så bra. Resultatet kan bli at både pasienten og legen sitter igjen med en følelse av at ingenting er blitt oppfattet. At legen vet hva som er i veien, er en forutsetning for at han skal kunne utføre arbeidet sitt på en god måte. Dermed kan språket vise seg å være nøkkelen eller et hinder i møte med legene.

En samisk kvinne opplevde språkbarrieren slik: «Når jeg er hos en norsktalende lege og begynner å fortelle om sykdommen min, oppdager jeg plutselig å bli diagnostisert med to sykdommer. Først den jeg gikk til legen med og så den jeg får mens jeg er hos legen. Resultatet er at jeg blir redd. På grunn av språket kan jeg dessverre ikke forklare meg så godt på norsk om det som feiler meg, og jeg frykter at legen misforstår meg.»

Jeg innrømmer gjerne at jeg slet med å møte opp til rett tid til legetimene de første årene i Norge. Fra å komme fra et samfunn der begrepet «African time» uten stress var gjeldende, måtte jeg sakte, men sikkert forandre meg dramatisk. I min nye tilværelse heter det nå «time is money». Her gjelder det å møte opp til rett tid til hver eneste legetime, enten jeg vil eller ikke!

Synet på sykdom og lidelser varierer også innen forskjellige kulturer. Mens vestlig medisin er naturvitenskapelig basert, anses sykdom i enkelte kulturer som besettelse eller straff. Måten personer med minoritetsbakgrunn håndterer kriser og sykdom på, kan også variere sterkt. I vestlige kulturer er det helt vanlig å greie seg selv. I Ghana, der jeg opprinnelig kommer fra, rådfører man seg gjerne med familien.

Jeg hadde ikke familien min å rådføre meg med i Norge da jeg slet med melkeintoleranse. Jeg husker bare jeg sprang på do hver gang jeg var borti melkeprodukter. Med svært begrensede norskkunnskaper og uten tolk til stede klarte jeg ikke å formidle problemet på en god måte slik at legen kunne fastsette en riktig diagnose tidlig - eller kanskje legen rett og slett manglet kunnskap om at en betydelig andel av personer med minoritetsbakgrunn har melkeintoleranse. Det måtte utallig legetimer til før diagnosen melkeintoleranse ble fastsatt.

Fleksibilitet og nytenkning når det gjelder rutiner og tilbud kan være en utfordring i legenes hverdag, som ofte preges av stort arbeidspress. Jeg mener at enkelte innvandrere og asylsøkere er ekstra sårbare, og bør møtes med fleksibilitet og nytenkning. En naturlig konklusjon er at de som trenger tettere oppfølging, bør får det.

Det er samtidig viktig å presisere at innvandrere og asylsøkere er like forskjellige som alle andre og må behandles deretter. Det finnes mange ressurssterke i denne gruppen også!

Baba danyagiri 